\title{
Dividend Decision and Economic Value Added of Quoted Nigeria Manufacturing Firms
}

\author{
Agilebu Ogechi Michael \\ Department of Banking and Finance \\ Rivers State University, Port Harcourt, Nigeria \\ E-mail: ogeberth2003@gmail.com
}

\begin{abstract}
This study examined the effect dividend decision and economic value added of quoted manufacturing firms in Nigeria. The objective is to examine if dividend decision have any effect on economic valued added of the Nigeria firms. Cross sectional data was sourced from financial statement of I5 quoted manufacturing firms. Economic valued added was proxy for dependent variables while dividend yield, dividend payout ratio, retention ratio and dividend per share were proxy for predictor variables. After cross examination of the validity of the pooled effect, fixed effect and the random effect, the study accepts the fixed effect model. Findings revealed that 75 percent variation from the fixed effect results on economic value added of the manufacturing firms. Beta coefficient of the predictor variables found that dividend yield have negative effect on economic value added while dividend per share, dividend payout ratio and retention ratio has positive and significant effect on economic value added of the quoted manufacturing firms. It's therefore recommend that constant dividend decision should be maintained among the quoted manufacturing firms and retention forms should be properly invested and the investment environment should be well managed to increase economic value added through the dividend decision channel.
\end{abstract}

Keywords: Dividend Decision, Economic Value Added, Quoted Nigeria Manufacturing Firms

\section{Introduction}

The accepted financial principle is that the role of managers is to maximize the wealth of shareholders by the efficient allocation of resources. In order to operationalise this objective, shareholder wealth is traditionally proxy by either standard accounting magnitudes such as profits, earnings and cash flows from operations or financial statement ratios including earnings per share and the returns on assets, investment and equity. This financial statement information is then used by managers, shareholders and other interested parties to assess current firm performance and also used by these same stakeholders to predict future performance. Further, under the semi-strong form of the efficient market hypothesis, the publicly available information contained in these variables is readily interpreted by the market and thereby incorporated into future stock prices (Damodaran, 2006a).

The conventional thought that dividend policy is relevant and matters on the performance of the firm can be traced to Graham and Dodd (1934) who were proponents of traditionalist schools of thought, later to Lintner (1956) and to Gordon (1960) while Miller and Modigliani (196I) argued that dividend policy is irrelevant under certain assumptions. Dividend policy decision is a finance management function (Ezirim, 2005). Dividend policy determines the proportion of company's profit that can be distributed to the shareholders as return on investment and proportion that will be retained for the company's reinvestment (Osegbu, Ifurueze and Ifurueze, 20I4). It is one of the most important financial decisions that corporate managers' encounter (M'rebetandBoujjat, 2016).Dividend policy is a micro determinant of firms' profitability. Firms adopt dividend policy that will facilitate the achievement of the organizational goals such as maximization of shareholders wealth. Like investment and capital structure decision, dividend policy influences the value and cost capital in the firm.

Unfortunately, the empirical literature to date suggests that there is no single finance based measure upon which one can rely to explain changes in shareholder wealth (Chen and Dodd, 1997; Riahi-Belkaoui, 1993; Rogerson, 1997; Lehn and Makhija, 1997; Akani and Lucky, 2015: Lucky, 2018; Anyamaobi and Lucky, 2018). This is despite the fact that such a measure would prove invaluable to the various parties interested in aspects of firm performance. Lee (1996) for example, argued that the search for a superior measure of firm valuation is not the, key feature of contemporary empirical finance. For years, investors and corporate managers have been seeking a timely and reliable measurement of shareholders' wealth. With such a measure, investors could spot over or underpriced stocks, lenders could gauge the security of their loans and managers could monitor the profitability of their factories, divisions and firms (Gay, Lin and Smith, 2010). One professedly recent innovation in the field of finance on performance measurement is an economic value-added. Economic value added is the financial performance measure that comes closer than any other to capturing the true economic profit of an enterprise. It is the 
performance measure most directly linked to the creation of shareholder wealth over time. From the above problems, this study examined the effect of corporate dividend decision on the economic value added of quoted firms in Nigeria.

\section{Literature Review}

\section{I Dividend Decision}

Dividend decision refers to a company's policy which determines the amount of dividend payments and the amounts of retained earnings for reinvesting in new projects. This decision is related to dividing the firm's earning between payment to shareholders and reinvestment in new opportunities. Dividend decision involves the determination of the payout policy that management follows in determining the size and pattern of cash distributions to shareholders over time (Lease et al, 2000).

Dividend decision was just concerned with selecting between payments of earnings to shareholder as cash dividend or retaining the profit in firm. It only determined the incidence of dividend payments and the amount dividends. However, in today's corporate finance, dividend policy addresses more issues such as how firms can attract investors in different tax brackets and how firms can increase the market value of firm and share repurchase instead of cash dividends.

\subsection{Types of Dividend Decision}

\subsection{Pure Residual Dividend Decision}

This states that when the corporation's return on equity capital is greater than the rate of return the investor could obtain by reinvesting those dividends in another investment of equivalent risk, the investor would rather the corporation act on his behalf and reinvest the earnings rather than issue a dividend; the firm can determine which option is better suited to benefiting the investor by first identifying the firm's optimal capital budget, thereby noting the level of equity capital required, and then maintaining the amount of earnings required to finance the equity capital in the capital budget and allowing "residual" funds (earnings not utilized in internal investment) after the mandated reinvestment to be issued as a dividend Droms (1990). Therefore, dividends are a function of earnings fluctuations, and this method allows for significant fluctuations in dividends with changes in earnings and corporate investment opportunities. In effect, all residual earnings are paid out which causes the dividend payout ratio to fluctuate. This policy also results in a dividend that varies from year to year, and when equity investment is greater than earnings, equity financing must be initiated to create a residual (Droms, 1990).

\subsubsection{Smoothed Residual Dividend Decision}

This suggests that dividend fluctuations are kept to a minimum. Dividend policy changes tend to lag behind earnings fluctuations according to Shapiro, as Dividends are set equal to the long-run residual between forecasted earnings and investment requirements. Dividend changes, in turn, are made only when this long run residual is expected to change; earnings fluctuations believed to be temporary are ignored in setting dividend payments, the clear preference is for a stable, but increasing, dividend per share (Shapiro, 1990). As such, the dividend payout ratio fluctuates significantly with this payment method, and dividends have the potential to exceed the residual if earnings are unexpectedly low.

\subsubsection{Constant or Fixed Decision}

The Company pays out a fixed amount of its profit after tax as dividend. Thus, the company maintains a fixed payout ratio of dividend. Pandey (2005) define payout as the ratio of dividend to earnings. A company may as a matter of policy, decide to constantly payout sixty percent of its after tax profit as dividend to its shareholders and retaining the remaining fraction. This type of policy allows the shareholders the opportunity to clearly know the amount of dividend to expect from their investments in the company. However as noted by Watson and Head (2004), the policy could be traumatic to companies experiencing a volatile or fluctuating profit earning. This is because of the uncertainty of its profit. If capital projects are to viable capital projects, the policy can be chaotic.

\subsubsection{Progressive Decision}

Payments on dividend are on a steady increase usually in line with inflation. This could result in increasing dividend in money terms. The firm uses the policy as a ratchet. Every effort is made to sustain the increase even though marginal. Seldom, the company may be constrained to cut down on dividend payout. This is to enable it sustain its operations. This though not a frequent action as it sends a wrong signal to investors. Firms operating this policy will opt to avoid paying dividends during the period rather than consistently cut down on the dividend (Kolb \& Rodriguez, 1996).

\subsubsection{Zero Dividend Decision}

Some firms may decide not to pay dividend. This is especially common in newly formed companies that rather require capital to execute its projects. All the profit is thus retained for expansion of the business. Investors who prefer capital gains to dividends 
because of taxation will naturally be lured by this kind of policy. This type of policy is quite easy to operate and avoids all the costs associated with payment of dividends Watson and Head (2004).

\subsubsection{Alternative Decision}

In order to give shareholders a choice between dividends or new shares, the company might choose to buy back shares. This is share or stock repurchase. This has a significant advantage in terms of tax to the shareholder. While the dividend is fully taxed just as ordinary income, the stock repurchase or buyback is not taxed until the shares are sold and the shareholder makes a profit or capital gain (Jordan, et al., 200I). There is also the policy of stock dividends and split. Shareholders are given additional shares in lieu of cash to the shareholders Brealey and Myers (2003).

\subsection{Economic Value-Added}

Despite the relatively recent adoption of economic value added as an internal and external financial performance measure, its conceptual underpinnings derive from a well-established microeconomic literature regarding the link between firm earnings and wealth creation (Bell, I998). For much of this history, at least since Alfred Marshall's Principles of Economics, the focus of analysis has been on adjustments to accounting earnings to reflect the opportunity cost of capital, primarily because the unadjusted measure can be a misleading indicator of performance in both theory and practice.

The desirability of quantifying economic profit as a measure of wealth creation was operationalised by David Solomon (I965) as the difference between two quantities, net earnings and the cost of capital. This measure of 'residual income' is then defined in terms of after-tax operating profits less a charge for invested capital which reflects the firm's weighted average cost of capital. Close parallels are thereby found in the related (non-trademarked) concepts of 'abnormal earnings excess earnings excess income excess realizable profits' and 'super profits' (Biddle et al., 1997).

The Economic Value Added (EVA) approach is a widely used excess return model. The cash flows, generated by an investment projects, that are smaller or larger than the required return (cost of capital) are called excess returns, and can be both negative and positive. Cash flows of investments that exactly yield the required rate of return are considered as normal returns.

The EVA of a project is obtained by multiplying the excess return of an investment by the amount of money invested (Damodaran, 2006a; Titman \& Martin, 2008). The calculation of firm value with the EVA model brings along some troubles. For example, to obtain the capital invested, often book values are used, which often do not reflect the proper (market) value of an asset and which could yield inaccurate valuations. In addition, Imam et al. (2008) found that, although the standard DCF model has the same structure of discounting cash flows and similar inputs, the EVA model was considered to be of very little importance by the interviewed analysts, whereas the standard DCF model was considered as highly important.

\subsection{Dividend Irrelevance Theory}

Modigliani and Miller (I96I) dividend-irrelevance theory says that investors can affect their return on a stock regardless of the stock's dividend. Investor could then buy more stock with the dividend that is over the investor's expectations. As such, the dividend is irrelevant to investors, meaning investors care little about a company's dividend policy since they can simulate their own.

Their theory was built on a range of key assumptions, similar to those on which they based their theory of capital structure irrelevancy. Modigliani and Miller (I96I) argue that the value of the firm in a perfect capital market depends only on the income produced by its assets not on how this income is split between dividends and the retained earnings. Assumed that in a perfect Capital markets, that is there are no taxes both corporate and personal taxes, no transaction costs on securities, investors are rational, information is symmetrical hence all investors have access to the same information and share the same expectations about the firm's future as its managers. According to M\&M's irrelevancy theory, if therefore does not matter how a firm divides its earnings between dividend payments to shareholders and internal retentions. Dividend irrelevancy theory asserts that a firm's dividend policy has no effect on its market value or its cost of capital.

\subsection{Bird in Hand Theory}

Gordon and Lintner (1959) the bird-in-the-hand theory states that dividends are relevant. The bird-in-the-hand may sound familiar as it is taken from an old saying; a bird in the hand is worth two in the bush. In this theory the bird in the hand' is referring to dividends and the bush is referring to capital gains. They argued that investors value dividends more than capital gains when making decisions related to stocks. As a company increases its payout ratio, investors become concerned that the company's future capital gains will dissipate since the retained earnings that the company reinvests into the business will be less. The essence of the bird-in-the-hand theory of dividend policy is that shareholders are risk-averse and prefer to receive dividend payments rather than future capital gains. Shareholders consider dividend payments to be more certain that future capital gains thus a bird in the hand is worth more than two in the bush. Gordon contended that the payment of current dividends resolves investor uncertainty. Investors have a preference for a certain level of income now rather that the prospect of a higher, but less 
certain, income at some time in the future. Investors' value a dollar expected dividend more highly than a dollar expected capital gain because the dividend yields component is less risky than the expected return hence, believed that investors require and prefer high dividends to capital gains resulting to a generous dividend policy by a firm.

\subsection{Information Asymmetry and Dividend Signaling}

Given information asymmetry as a market imperfection, the signaling concept of financial capital structure can be readily applied to dividend policy. According to the dividend signaling theory, a firm that increases its dividend payouts is signaling that it has expected future cash flows sufficient to meet expenses without increasing the probability of bankruptcy. Managers signal investors because financial managers have privileged information about the firm's expected cash flows that outside investors cannot know. Bhattacharya (1979) proposes a dividend signaling model to explain why firms pay dividends despite the apparent tax disadvantage. In Bhattacharya's (1979) dividend signaling model, investors believe that an unexpected dividend increase is a favorable signal. This assumes that the dividend contains information regarding firm value not conveyed in other public information, and that the dividend is a valid signal since it is expensive for less valuable firms to mimic. Then the signaling value of dividends is positive and can be traded off against the tax costs. The implication of such a dividend signaling model is that it suggests an optimal dividend policy where the signaling benefits of paying dividends offsets the tax disadvantages of paying dividends.

\subsection{Empirical Review}

Eniola and Akinselure (2016) examined the impact of Dividend policy and Earnings on selected quoted companies in Nigeria. The secondary data were obtained through the internet from stock broking firm's online database. Multiple regression and Durbin Watson in testing was used in the hypothesis considered in this study, and the statistical analysis was done using Statistical Package for Social Sciences (SPSS version 20). The findings revealed that there was a significant relationship between dividend and market value but, this relationship can only be established between earning per share and divide and yield, because, it is the only proxies of divide and polices that had a P-value (0.020) which is less than the alpha value of (0.05) which implies that there is relationship with market value proxy (earnings per share) while the other proxies of dividend policy did not show any relationship.

Momgbe and Ibrahim (2014) ascertained the relationship between dividend policy and corporate profitability, Investment and Earning per shares. Data for the study were extracted from annual report and accounts of twenty five quoted companies in Nigeria. The study found positive and significant association between the firm performance and dividend policy of the sampled firm. Richard and Thomas (20I4) ascertained the impact of dividend payout on the financial performance of manufacturing firms which trade on the Ghana Stock Exchange. Panel data extracted from audited financial statements of sampled firms from 2004 to 20 I I financial years were analyzed within the framework of the fixed effects model after carrying out Hausman specification test. The descriptive statistics show that the average dividend payout is $32.93 \%$ while the mean performance (return on assets) is $1.08 \%$ during the study period. The regression results reveal that dividend payout significantly but negatively impacts on quoted manufacturing firms' financial performance in Ghana. For the control variables, size and leverage were inversely related to performance whiles sales growth positively correlated with performance. Except size, all the control variables were found to be statistically significant.

M'rbet and Boujjat(2016)examined the relationship between dividend policies and financial performance of selected listed firms in Morocco. Data were sourced through secondary means from the annual reports of the sampled quoted firms and was analyzed using panel data regression model. Two models were developed in an attempt to provide a theoretical explanation on the birds-in-hand dividend relevance theory and the Modigliani and Miller's (MM) dividend irrelevance theory. The findings indicated that Dividend policy is an important factor affecting firm performance. Their relationship was also strong and positive. This therefore showed that dividend policy was relevant. It can be concluded, based on the findings of this research that dividend policy is relevant and that managers should devote adequate time in designing a dividend policy that will enhance firm performance and therefore shareholder value.

Sunday et. al (2015) are examining the relationship between dividend policy and financial performance of nonfinancial firms in Nigeria. They had selected 25 listed non-financial firms in Nigeria with supported by the below theoretical empirical studies and secondary data sources, the audited report of the firms had chosen. Panel data methodology was employed and pooled Ordinary Least Squares (OLS) was used to estimate the coefficients of explanatory and control variables where the return on assets (ROA) served as the dependent variable, profitability, while dividend payout ratio proxies for dividend policy and was the only explanatory variable. Result reveals a positive and significant relationship between dividend pay-out policy (DPO) and firm performance (ROA). This finding is consistent with some prior empirical studies and provides evidence in support of both Signaling and Bird -in- hand hypotheses of dividend policy theory.

Barman (2008) did a survey designed to achieve an independent analysis of the dividend function used by companies in South Africa. The study consisted of a sample of 42 companies both listed and private in South Africa which paid a cash 
dividend during the previous financial year (2007). Questionnaires were sent out to the Chief Financial Officer (CFO's) of both listed and private firms to get managers' view on dividend payments and the effect it has on firm value. Barman study was based on questionnaires that aimed to get managers view on dividend policy and its impact on firm value in South Africa. However the samples of 42 listed and private companies that selected relatively small. Therefore, the results of the study are only indicative and not conclusive. According to his findings, managements are of the view that optimal policy strike a balance between dividend payment and the growth of a firm; about half of managers interviewed are neutral when asked if they think dividends policy has an impact on firm value. It appears that management do view dividend policy as being important, however majority of the managers do not think dividend policy have an effect on the intrinsic value of shares.

Azhagaiah and Priya (2008) did a study which aimed at analyzing the impact of dividend policy on shareholders' wealth in organic and chemical Companies in India. In order to measure the impact of dividend policy on shareholders' wealth, they used multiple regression models and stepwise regression models. They used Market Price per Share as the dependent variable and Dividend per share, Retained Earnings per Share, Lagged Price Earning Ration and Lagged Market Price as the independent variable. In comparing dividend and non-dividend paying firms they found that in the long-run, the wealth of shareholders in dividend paying chemical companies had increased significantly. This indicated the impact of dividend policy on wealth creation. The regression analysis indicates that dividend payments by organic and chemical companies have a positive and significant impact on their shareholders' wealth. The authors indicated that shareholders prefer current dividend to future income, as dividends are considered as an important factor which determines shareholders 'wealth.

Agyei and Marfo-Yiadom (20II) studied the relationship between dividend policy and performance of I6 commercial banks in Ghana for a period of 5 years (1993-2003). Result shows a positive relationship between dividend policy and performance. It further reveals that leverage, size of bank and growth, enhance the performance of banks.

Uwuigbe, Jafaru and Ajayi (2012) investigate the relationship between the financial performance and dividend payout among 50 listed firms in Nigeria for 2006 to 2010. Result shows a significant and positive association between the performance of firms and the dividend pay-out. The study also reveals that ownership structure and firm's size has a significant impact on dividend pay-out of firms.

Merekefu and Ouma (2012) examined the relationship between dividend pay-out and firm performance. The study was based on 4I companies listed on the Nairobi Securities Exchange from 2002-20I0. They did a regression analysis to determine the relationship between dividend payout and firm performance. Net profit margin was the dependent variable, while dividends paid; total assets and revenue were the independent variables. The results indicated that about $80.7 \%$ of net profit after tax was influenced by dividends paid, total assets and revenue. They found a positive strong relationship between Net profit after tax and dividends.

Gul (2012) examined in Pakistan testing the relationship between dividend policy and shareholders' wealth. The study was based on a sample of 72 companies listed on the Karachi Stock Exchange from 2005-2010. The authors used multiple regression and stepwise regression method to study the impact of dividend policy on shareholders' wealth. Market value of equity is the depended variable and was used as a proxy for measuring shareholders' wealth. The independent variables include dividend per share, retained earnings, lagged price to earnings ratio and lagged market value of equity. Dividend per share was used as a proxy for measuring the dividend policy of a firm.

Gul (2012) found that the market value of companies that pay dividends is well above the book value as compared to companies that do not pay dividends. They reported that there is a significant difference between shareholders' wealth in companies that pay dividends than those that do not pay dividends. Their findings also indicate that the wealth of dividend payers increased significantly as compared to non- payers, which shows the impact of dividend policy on shareholders 'wealth. The regression analysis on the 4 models are significant at a I\% level and the results indicate that dividend per share has a significant positive influence on the dependent variable in all models except model 3 . These suggest that the higher the companies pay dividend per share the higher shareholders wealth will be.

Timothy and Peter (2012) sought to establish the relationship between dividend payout and firm performance among listed firms on the Nairobi Securities Exchange during the period of 2002 -2010. They employed regression analysis to establish the relationship between dividend payout and firm performance. Their findings indicated that dividend payout was a major factor affecting firm profitability measured by net profit after tax. Their relationship was also strong and positive. This therefore showed that dividend policy was relevant.

Salehnezhad (2013) investigates corporate governance and dividend policy in firms listed in Tehran Stock Exchange for the period 2010 to 2012. Using fuzzy regression analysis, the result shows that a positive relationship exists between financial performance (stock returns) and dividend policy. Dwita AyuRizqia, SitiAisjahSimiati (20I3) study the effect of managerial ownership, financial leverage, profitability, firm size and investment opportunity on dividend policy and effect of all that variables on firm value on manufacturing firms that go-public and listed in Indonesia Stock Exchange during 2006-20II. During 2006-2009, the manufacturing sector growth is declining which will hinder goal to increase firm value. There were I5 firms committed to distribute dividends for 5consecutive years during 2007-20II and most of I5 firms decided large 
percentage of retained earnings. This also shows management decisions making influenced by distribution and growth of firm profitable investment opportunities. The sample was decided by census method. They had tested that most of the firms tend to pay dividend to the investors that believe will increase the firm share price as shareholder believe only a firm with good profit is able to payout dividend.

Ajanthan (2013) did a study in Sri Lanka on the relationship between dividend payout and profitability among listed hotels and restaurant companies on the Colombo Stock Exchange. A than did a regression and correlation analysis to test the relationship between dividend payout and firm profitability. Conclusion is that based on the results "dividend policy is relevant and that managers should pay attention and devote adequate time in designing a dividend policy that will enhance firm profitability and therefore shareholder value.

Oyinlola and Ajeigbe (2013) examined the impact of dividend policy on the stock prices of 22quoted firms in Nigeria during the period 2009 to 2013. Regression analysis, correlation analysisandGranger Causality Test was used to test research hypothesis on IIO observations. Findings reveal that both dividend payout and retained earnings are significantly relevant to the market per share of the firms. Oyinlola, Oyinlola and Adeniran (20I4) investigated the impact of performance on the dividend policy of two major brewery firms quoted on the Nigerian Stock Exchange for the period 2002-2010. Findings reveal that dividend policy is relevant and that a firm's dividend policy is seen as a major determinant for a firm's performance. Positive relationship exists between the dividend policy and performance.

Osegbuet al (2014) analyses the extent of relationships between dividend payment and corporate performance in the Nigerian banking industry between 1990 and 2010. Using regression models, the result shows no significant relation between dividend policy and performance. Interestingly, insignificant relationship occurs between dividend policy and other four explanatory variables (free cash flow, financial leverage, business risk and tax paid on dividend payment ratio).

Charles et al (20I4) conducted a study to ascertaining the relationship between dividend policy and firm's profitability, investment per shares. The data of this study were extracted from annual report and accounts of 2013 and 9 manufacturing firm is selected in Nairobi Stock Exchange of Kenya and other empirical study. It was discovered that the dividend policies of organizations have a significant positive relationship with profitability, investments and earnings per share of corporate organization. They proved that dividend policies of organizations are vital in enhancing the profitability and investment of manufacturing sector in Kenya.

Fathima et al (2014), sought the impact of dividend payout on corporate profitability in the Manufacturing Companies listed on Colombo Stock Exchange in Sri Lanka. For this purpose, the data were extracted from the annual reports of the 2I manufacturing companies during the period from 2007-20II. Regression model is used to study and estimate the relationship between dividend payout and corporate profitability. The study also employed a subsample in order to arrive at a profound conclusion with regard to the impact of dividend policy on corporate profitability. The results of the study revealed that there was a significant relationship between dividend payout and corporate profitability in terms of return on assets, return on equity and earnings per share. A positive significant relation is found between dividend payout and return on assets and return on equity for the whole sample while significant negative relationship is found between dividend payout and earnings per share as far as the dividend paying sample is concerned.

Ifueroet al. (2016) conducted a study of effect of dividend policy on firm's returns using data of seventeen (I7) manufacturing firms listed on the Nigerian stock Exchange by using descriptive statistics, correlation analysis and panel regression technique, where the fixed effect regression. The finding reveal that current dividend payout, growth opportunity of firms and dividend per share has positive and significant effect on earnings per share, with that of growth having an overwhelming influence. Current dividend payout and dividend per share are both significant at the 5\% level. One lagged dividend payout (previous dividend payout), cash flow and leverage have positive but not significant influence on EPS, while the impact of size is negative and not significant. Tax Preference theory stated that tax treatment may influence on the distributed income of a firm. An example given in the article, if the investors in high tax bracket might require higher pre-tax risk adjusted premium returns to hold stocks with higher dividend yield.

Farsio et al. (2004) argue that there is no significant relationship between dividends and earnings hold in the long run and studies that support this relationship are based on short periods and therefore misleading to investors. As it point out that an increase in dividends many lead to a decline in funds that are to be reinvested and pay high dividend without considering investment needs may lead to lower future earnings. Thus is a negative relationship between dividend payout and future earnings. Grullanet al. (2005)revealed that dividends changes are very poor indicators of both earnings and profitability levels hence concluded that there is no evidence supporting the idea that dividend increases signal better prospects for firm profitability.

Yusuf (2015) examined the impact of performance on dividend payout ratio of some selected commercial banks in Nigeria spanning the periods between 2004 and 2013. Guided by explanatory research design, four commercial banks were selected and data relating to relevant variables of leverage and profitability and dividend payout ratio were gathered. Correlation analysis and multiple regressions were carried out to analyses the data. The findings revealed that dividend payout ratio is 
negatively related to banks' leverage and profitability. The study concludes that dividend payout ratio is inversely related to performance of commercial banks in Nigeria.

Simon-Oke and Ologdinwa (2016) evaluated the effect of dividend policy on corporate performance in Nigeria, using time series data generated from secondary sources through the publications of Nigeria Stock Exchange and financial statements of the companies under review. The study also employed OLS multiple regression analytical techniques to establish the relationships among the variables of dividend policy and the corporate performance of firms in Nigeria. The findings reveal that dividend policy in Nigeria still remains a function of strong dynamic variables such as return on investment (ROI), earnings per share (EPS) and dividend per share (DPS).

Osegbu,Ifurueze and Ifurueze(2014) analyzed the extent of relationships between dividend payment and corporate performance in the Nigerian banking industry. The study uses a panel data set of banks listed on the Nigeria stock exchange between the year 1990 and 20I0. The five hypotheses were applied to examine the extent and the level of significance of the relationship between the amount of dividend payment and corporate performance using regression models. The research indicated that there is no significant relationship between dividend payout of banks in Nigeria and the explanatory variables.

Uwuigbe (2012) investigated the relationship between the financial performance and dividend payout among listed firms' in Nigeria. It also looks at the relationship between ownership structure, size of firms and the dividend payouts. The annual reports for the period2006-2010 were utilized as the main source of data collection for the50 sampled firms. The regression analysis method was employed as a statistical technique for analyzing the data collected. The study found that that there is a significant positive association between the performance of firms and the dividend payout of the sampled firms in Nigeria. The study also revealed that ownership structure and firm's size has a significant impact of the dividend payout of firms too.

Nwannamka and Ezeabsili (2017) examined the effects of dividend policy on firm value. The study covers I0 quoted companies studied for the period of 1995-2015. The methodology adopted is the ordinary least square regression analysis for primary data analyses and multiple regression analysis for the secondary data analyses with models MPS (Market Price per Share) as dependent variable, EPS (Earnings per Share) and DPS (Dividend Per Share) as independent variables. The study shows the relevance of dividend, dividend as a signaling model and proves that firm value is greatly influenced by dividend policy as far as public limited companies are concerned.

Peter and Lyndon (2016) this study investigated the relationship between dividend payout policyand firm performance in Nigeria, using a sample of some listed firms in the Nigerian Stock Exchange (NSE) for the period 2002 to 2012. The study adopted comparative/descriptive research designs as a set of time series dimension of panel data estimation techniques were utilized. The result shows a positive and significant relationship between dividend payout policy and profit after $\operatorname{tax}$ (PAT). This result indicates that dividend payout policy enhances firm performance in Nigeria. While earning per share (EPS) had a negative influence on dividend payout policy of firms in Nigeria for the period the study covered.

Rheman and Hussain(2017) tried to find out the key indicators that do impact the performance of the firm and are also incorporated in the dividend policy of the firm. Ratios have been computed of all the companies that basically determine the dividend policy and then the correlation tests have been run to see the whether the results are significant or not. In the conclusion we have mentioned the variables that play a key role in determining the performance of the firms

Ojeme, Mamid and Ojo, (2015) examined empirically the implications of adopted dividend policies on the value of shareholders' wealth and the extent to which dividend policy affects the market value of shares in quoted banks in Nigeria. The paper focuses on the situation before and after the financial meltdown. Correlation results of dividend paid in 2007-2010 and their corresponding market value showed that payment of dividend by quoted banks is relevant to their market value and the amount paid as dividend affects the value of their share. Findings revealed the effects of policy decisions as it affects dividend payout and dividend retained for further growth on shareholders 'wealth.

\section{Research Methodology}

Descriptive and longitudinal design was employed with a view to making statistical inferences on the effect leverage on corpo rate financial distress of manufacturing firms. A Sampling frame of I5 quoted manufacturing firms was selected using random sampling techniques. The required cross-sectional data were sourced from annual reports of the firms and stock exchange factbook from 2008-2017.

\section{I Analytical Framework and Empirical Model Specification}

This analysis is carried out within a panel data estimation framework. The preference of this estimation method is not only because it enables a cross-sectional time series analysis which usually makes provision for broader set of data points, but also because of its ability to control for heterogeneity and endogencity issues. Hence panel data estimation allows for the control of 
individual-specific effects usually unobservable which may be correlated with other explanatory variables included in the specification of the relationship between dependent and explanatory variables (Hausman and Taylor, I98I). The basic framework for panel data regression takes the form:

$Y_{i t}=\beta X^{\prime}{ }_{i t}+\alpha Z^{\prime}{ }_{i}+\varepsilon_{i t}$

Where:

\begin{tabular}{|c|c|c|}
\hline D & $\begin{aligned} \mathrm{Y} & = \\
& =\end{aligned}$ & $\begin{array}{l}\text { dependent variable } \\
\text { independent variable }\end{array}$ \\
\hline$\beta_{o}$ & $=$ & intercept \\
\hline$\beta_{i}$ & $=$ & coefficient of the explanatory variable \\
\hline $\mathrm{e}$ & . & error term \\
\hline & - & cross-sectional variable \\
\hline
\end{tabular}

In the equation above, the heterogeneity or individual effect is $Z^{i}$ which may represent a constant term and a set of observable and unobservable variables. When the individual effect $Z^{\prime}{ }_{i}$ contains only a constant term, OLS estimation provides a consistent and efficient estimates of the underlying parameters (Kyereboah-Coleman, 2007); hut if $Z^{\prime}{ }_{i}$ is un-observable and correlated with $X_{i t}$, then emerges the need to use other estimation method because OLS will give rise to biased and inconsistent estimates. Similarly for endogeneity issues, it is generally assumed that the explanatory variables located on the right hand side of the regression equation are statistically independent of the disturbance $\varepsilon_{i t}$ such that the disturbance term $\varepsilon_{i t}$ is assumed to be uncorrelated with columns of the parameters $X_{i t}$ and $Z_{i t}$ as stated in equation (I), and has zero mean and constant variance $\sigma^{2} \eta$ (Hausman and Taylor, 198). If this assumption is violated, then OLS estimation will yield biased estimates of the underlying parameters of $\beta$ (Mayston, 2002).Hence, endogeneitv problems arise when the explanatory variables are correlated with the disturbance term $\varepsilon_{i t}$ (Mayston, 2002; Hausman and Taylor, I98I). In order to circumvent these problems, panel estimation techniques of fixed and random effects will be adopted in this study, in addition to the traditional pooled regression estimation. Decisions will be made between the fixed and random effect models using the Hausman specification test. The panel model for the study is specified base on the modified model of Lucky (2018).

\section{Model Specification}

Pooled regression specification

$E V A_{i}=\alpha O+\alpha_{1} D D P R_{1 i}+\alpha_{2} R R_{2 i}+D Y_{3 i t}+\alpha_{3} D P S_{4 i t}+\mu$

Fixed Effect Model Specification

$E V A_{i t}=\alpha o++\alpha_{1} D P R_{1 i}+\alpha_{2} R R_{2 i}+D Y_{3 i t}+\alpha_{3} D P S_{4 i t}+\quad \sum_{i}^{9}=1 \alpha_{i} i d u m+\varepsilon 1_{i t}$

\section{Random effect model specification}

$E V A_{i t}=\alpha o+\alpha_{1}+\alpha_{1} D P R_{1 i}+\alpha_{2} R R_{2 i}+D Y_{3 i t}+\alpha_{3} D P S_{4 i t}+\quad+\mu i+\varepsilon 1_{i t}$

Where

EVA $=$ Economic Value added of the quoted firms

DPR $=$ Dividend payout rate

$\mathrm{RR} \quad=\quad$ Retention Rate

DY $\quad=\quad$ Dividend yield

DPS $=$ dividend per share

$\mu \quad=\quad$ Stochastic or disturbance/error term.

$\mathrm{t}=$ Time dimension of the variables

$\alpha 0=$ Constant or intercept. 


\section{Estimation Techniques \\ Panel unit root test result}

The data were checked for the presence of unit root using the ADF Fisher Chi-Square andPhiliperon Fisher Chi-Square, which is based on the well-known Dickey-Fuller procedure. The null hypothesis for these tests is that there is a presence of nonstationary series against the alternative hypothesis of stationary series. The unit root test is important because non-stationary series regression estimation leads to spurious regression estimations with the wrong magnitude and sign of the parameter of the regressors, with wrongly inferred implications. The study assumes an absence of a time trend; hence it is tested for stationarity allowing for constant only. Stationarity denotes the non existence of unit root. We shall therefore subject all the variables to unit root test using the augmented Dickey Fuller (ADF) test specified in Gujarati (2004) as follows.

$$
\Delta y_{t}=\beta_{1}+\beta_{2}+\delta y_{t-1}+\alpha i \sum_{i-1}^{m} \Delta y_{t-1}+E t
$$

Where:

$\begin{array}{lll}\Delta y_{t} & = & \text { change time t } \\ \Delta y_{t-1} & = & \text { the lagged value of the dependent variables } \\ \Sigma_{t} & = & \text { White noise error term }\end{array}$

If in the above $\delta=0$, then we conclude that there is a unit root. Otherwise there is no unit root, meaning that it is stationary. The choice of lag will be determined by Akaike information criteria.

\section{Decision Rule}

$\mathrm{t}-\mathrm{ADF}$ (absolute value) $>\mathrm{t}-\mathrm{ADF}$ (critical value) : Reject $\mathrm{H}_{\mathrm{o}}$ (otherwise accept $\mathrm{H}_{\mathrm{I}}$ )

Note that each variable will have its own ADF test value. If the variables are stationary at level, then they are integrated of order zero i.e $\mathrm{I}(0)$. The unit root problem earlier mentioned can be explained using the model:

$\mathrm{Y}=\mathrm{Y}_{\mathrm{t}-\mathrm{I}}+\mu_{\mathrm{I}}$

Where $Y t$ is the variable in question; $\mu_{i}$ is stochastic error term. Equation (a) is termed first order regression because we regress the value $\mathrm{Y}$ at time " $\mathrm{t}$ " on its value at time $(\mathrm{t}-\mathrm{I})$. If the coefficient of $\mathrm{Y}_{\mathrm{t}-\mathrm{i}}$ is equal to $\mathrm{I}$, then we have a unit root problem (non stationary situation). This means that if the regression.

$\mathrm{Y}=\mathrm{Y}_{\mathrm{t}-\mathrm{I}}+\mu_{\mathrm{I}}$

Is run and $\mathrm{L}$ is found to be equal to $\mathrm{I}$ then the variable $\mathrm{Yt}$ has a unit root (random work in time series econometrics).

If a time series has a unit root, the first difference of such time series are usually stationary. Therefore to salve the problem, take the first difference of the time series. The first difference operation is shown in the following model:

$\Delta \mathrm{Y}=(\mathrm{L}-\mathrm{I}) \mathrm{Y}_{\mathrm{t}-\mathrm{I}}+\mu_{\mathrm{I}}$

$\delta \mathrm{Y}_{\mathrm{t}-\mathrm{I}}+\mu_{\mathrm{I}}$

(Note: $\delta=\mathrm{I}-\mathrm{I}=0$; where $\mathrm{L}=\mathrm{I} ; \Delta \mathrm{Yt}=\mathrm{Yt}-\mathrm{Y}_{\mathrm{t}-\mathrm{i}}$ )

\section{Integrated Of Order I Or I(I)}

Given that the original (random walk) series is differenced once and the differenced series becomes stationary, then the original series is said to be integrated of order I or I (I).

\section{Integrated of Order 2 Or I (2)}

Given that the original series is differenced twice before it becomes stationary (the first difference of the first difference), then the original series is integrated of order 2 or $\mathrm{I}(2)$.

Therefore, given a time series has to be differenced Q times before becoming stationary it said to be integrated of order Q or I (q). Hence, non-stationary time series are those that are integrated of order I or greater.

The null hypothesis for the unit root is: Ho: $\mathrm{a}=\mathrm{I}$;

The alternative hypothesis is Hi: a $<\mathrm{I}$.

We shall test the stationarity of our data using the ADF test. 


\section{Granger Causality Test}

Thus, Granger causality test helps in adequate specification of model. In Granger causality, test, the null hypothesis is that no causality between two variables. The null hypotheses is rejected if the probability of $F^{*}$ statistics given in the Granger causality result is less than 0.05 .

The pair-wise granger causality test is mathematically expressed as:

$$
Y_{t} \pi_{o}+\sum_{i=1}^{n} x_{1}{ }^{y} Y_{t-1} \sum_{i=1}^{n} \pi_{1}^{x} x_{t-1}+u_{1}
$$

and

$$
\mathrm{x}_{\mathrm{t}} \mathrm{dp} \mathrm{p}_{\mathrm{o}}+\sum_{\mathrm{i}=1}^{\mathrm{n}} \mathrm{dp} \mathrm{p}_{1}^{\mathrm{y}} \mathrm{Yt}-1 \sum_{\mathrm{i}=1}^{\mathrm{n}} \mathrm{dp} 1^{\mathrm{x}} \mathrm{x}_{\mathrm{y}-1}+\mathrm{V}_{1}
$$

Where $\mathrm{x}_{\mathrm{t}}$ and $\mathrm{y}_{\mathrm{t}}$ are the variables to be tested white $\mathrm{u}_{\mathrm{t}}$ and $\mathrm{v}_{\mathrm{t}}$ are the white noise disturbance terms. The null hypothesis $\pi_{1}^{y}=d p_{1}^{y}=0$, for all I's is tested against the alternative hypothesis $\pi_{1}^{x} \neq 0$ and $d p_{1}^{y} \neq 0$. if the co-efficient of $\pi_{1}^{x}$ are statistically significant but that of $d p 1 y$ are not, then $\mathrm{x}$ causes $\mathrm{y}$. If the reverse is true then $\mathrm{y}$ causes $\mathrm{x}$. however, where both co-efficient of $\pi_{1}^{x}$ and $d p_{1}^{y}$ are significant then causality is bi-directional

\section{Presentation of Results and Discussion of Findings}

The following tables explain the dynamic relationship between dividend decision and economic value added of the selected manufacturing firms in Nigeria.

\begin{tabular}{|c|c|c|c|}
\hline \multicolumn{4}{|c|}{ Redundant Fixed Effects Tests } \\
\hline Effects Test & Statistic & d.f. & Prob. \\
\hline Cross-section F & 2.698090 & $(\mathrm{I} 4,7 \mathrm{I})$ & 0.0032 \\
\hline Cross-section Chi-square & 38.392708 & $\mathrm{I} 4$ & 0.0005 \\
\hline \multicolumn{4}{|c|}{ Correlated Random Effects - Hausman Test } \\
\hline Test Summary & $\begin{array}{l}\text { Chi-Sq. } \\
\text { Statistic }\end{array}$ & Chi-Sq. d.f. & Prob. \\
\hline Cross-section random & II.03I48I & 4 & 0.0050 \\
\hline
\end{tabular}

Table I: Test of Appropriate Model

Source: Extract from E-view 9.0, 2019

Our study used the likelihood ratio test to choose between the Pooled effect model and the fixed effects model as how in table i above.

The fixed effects model is better than pooled effect that the results of the likelihood ratio test were significant ( $p$ value $<0.0000$ for the three models. This result means that we reject the Pooled effect model and choose the fixed effects model for this study. To make a choice between the fixed effects model and the random effects model, we utilized the Hausman test as shown in the table above. The hypotheses of the test are as follows:

The fixed effects model is more appropriate than the random effects model. As the result found that the results of this test were significant $(p$-value $=0.024 \mathrm{I})$. Hence, we reject the null hypothesis and conclude that the fixed effects model is the most appropriate of the three models.

\begin{tabular}{|c|c|c|c|c|c|}
\hline Variable & Coefficient & & Std. Error & t-Statistic & \\
\hline DY & & -0.149415 & 0.112713 & -1.325624 & 0.1885 \\
\hline DPS & & 0.207417 & 0.141753 & 1.463223 & $0.147 \mathrm{I}$ \\
\hline DPR & & 0.11027 I & 0.130836 & 0.842817 & 0.4017 \\
\hline RR & & 0.106482 & 0.129402 & 0.822877 & 0.4129 \\
\hline $\mathrm{C}$ & & -0.830492 & 12.99663 & -0.063901 & 0.9492 \\
\hline R-squared & & 0.057177 & Mean dependent var & & I0.19322 \\
\hline Adjusted R-squared & & 0.012809 & S.D. dependent var & & $\mathrm{I} .29276 \mathrm{I}$ \\
\hline S.E. of regression & & I.284455 & Akaike info criterion & & 3.392498 \\
\hline
\end{tabular}

Table II: Presentation of Pooled Regression Model 


\begin{tabular}{lcll}
\hline Sum squared resid & I 40.2350 & Schwarz criterion & 3.531377 \\
\hline Log likelihood & $-\mathrm{I} 47.6624$ & Hannan-Quinn criter. & 3.448502 \\
\hline F-statistic & I.28870I & Durbin-Watson stat & 0.940905 \\
\hline Prob(F-statistic) & 0.280916 & & \\
\hline
\end{tabular}

Source: Extract from E-view 9.0, 2019

Table III: Presentation of Fixed Regression Model

\begin{tabular}{|c|c|c|c|c|}
\hline Variable & Coefficient & Std. Error & & Prob. \\
\hline$\overline{D Y}$ & -0.891660 & 0.162539 & -2.179168 & 0.0003 \\
\hline DPS & $0.15467 \mathrm{I}$ & 0.151752 & 2.019236 & 0.0006 \\
\hline DPR & 0.034566 & 0.126994 & 0.272183 & 0.7863 \\
\hline RR & 0.831367 & 0.125502 & 2.249929 & 0.0034 \\
\hline $\mathrm{C}$ & $7.15840 \mathrm{I}$ & $\mathrm{I} 2.56055$ & $0.5699 \mathrm{II}$ & 0.0000 \\
\hline \multicolumn{5}{|c|}{ Effects Specification } \\
\hline \multicolumn{5}{|c|}{ Cross-section fixed (dummy variables) } \\
\hline R-squared & 0.784588 & Mean dependent var & & I0.19322 \\
\hline Adjusted R-squared & 0.528568 & S.D. dependent var & & I.29276I \\
\hline S.E. of regression & I.I35448 & Akaike info criterion & & 3.277024 \\
\hline Sum squared resid & 91.53618 & Schwarz criterion & & 3.804762 \\
\hline Log likelihood & $-\mathrm{I} 28.466 \mathrm{I}$ & Hannan-Quinn criter. & & 3.489839 \\
\hline F-statistic & 2.464988 & Durbin-Watson stat & & I.5I695I \\
\hline Prob(F-statistic) & 0.003743 & & & \\
\hline
\end{tabular}

Table IV: Presentation of Random Regression Model

\begin{tabular}{|c|c|c|c|c|}
\hline Variable & Coefficient & Std. Error & & Prob. \\
\hline DY & -0.171352 & 0.133486 & $-\mathrm{I} .28367 \mathrm{I}$ & 0.2027 \\
\hline DPS & 0.174799 & 0.142437 & I.227208 & $0.223 \mathrm{I}$ \\
\hline $\mathrm{DPR}$ & 0.058288 & 0.123147 & 0.473324 & 0.6372 \\
\hline $\mathrm{RR}$ & 0.055083 & 0.121769 & 0.452358 & 0.6522 \\
\hline $\mathrm{C}$ & 4.594668 & $\mathrm{I} 2.21246$ & 0.376228 & 0.7077 \\
\hline \multicolumn{5}{|c|}{ Effects Specification } \\
\hline & & & S.D. & Rho \\
\hline Cross-section random & & & 0.728365 & 0.2915 \\
\hline Idiosyncratic random & & & I.I35448 & 0.7085 \\
\hline \multicolumn{5}{|c|}{ Weighted Statistics } \\
\hline R-squared & 0.443535 & Mean dependent var & & 5.472827 \\
\hline Adjusted R-squared & 0.301475 & S.D. dependent var & & I.I I4623 \\
\hline S.E. of regression & I.I I5445 & Sum squared resid & & 105.7584 \\
\hline F-statistic & 0.967237 & Durbin-Watson stat & & I.237294 \\
\hline Prob(F-statistic) & 0.429844 & & & \\
\hline \multicolumn{5}{|c|}{ Unweighted Statistics } \\
\hline R-squared & 0.454425 & Mean dependent var & & 10.19322 \\
\hline Sum squared resid & $\mathrm{I} 40.6444$ & Durbin-Watson stat & & 0.931586 \\
\hline
\end{tabular}

Table V: Cross-Section Random Effects Test Comparisons

\begin{tabular}{|c|c|c|c|c|}
\hline Variable & Fixed & Random & Var(Diff.) & \\
\hline DY & -0.191660 & -0.17 I352 & 0.008600 & 0.8267 \\
\hline DPS & $0.15467 \mathrm{I}$ & 0.174799 & $0.00274 \mathrm{I}$ & 0.7006 \\
\hline DPR & 0.034566 & 0.058288 & 0.000962 & 0.4444 \\
\hline RR & 0.031367 & 0.055083 & 0.000923 & 0.4350 \\
\hline
\end{tabular}


Table VI: Presentation Of Causality Test

\begin{tabular}{lccc}
\hline Null Hypothesis: & Obs & F-Statistic & Prob. \\
\hline DY does not Granger Cause EVA & 60 & 0.32035 & 0.7272 \\
\hline EVAdoes not Granger Cause DY & & 0.15716 & 0.8550 \\
\hline DPS does not Granger Cause EVA & 60 & 0.32299 & 0.7253 \\
\hline EVA does not Granger Cause DPS & & 0.21823 & 0.8046 \\
\hline DPR does not Granger Cause EVA & 60 & 1.17205 & 0.3173 \\
\hline EVA does not Granger Cause DPR & & 1.49205 & 0.2339 \\
\hline RR does not Granger Cause EVA & 60 & 0.86169 & 0.4281 \\
\hline EVA does not Granger Cause RR & & 1.52567 & 0.2265 \\
\hline
\end{tabular}

Source: Extract from E-view 9.0, 2019

Table VII: Test for Stationarity

\begin{tabular}{llcccc}
\hline Variables & ADF - Fisher Chi-square/ PP - Fisher Chi-square & Statistics & Probability & REMARK & DECISION \\
\hline EVA & PP - Fisher Chi-square & 73.4606 & 0.0000 & Stationary & Reject H0 \\
\hline & PP - Choi Z-stat & -2.69812 & 0.0035 & Stationary & Reject H0 \\
\hline RR & PP - Fisher Chi-square & 74.3608 & 0.0000 & Stationary & Reject H0 \\
\hline & PP - Choi Z-stat & -4.04781 & 0.0000 & Stationary & Reject H0 \\
\hline DY & PP - Fisher Chi-square & 60.9287 & 0.0007 & Stationary & Reject H0 \\
\hline & PP - Choi Z-stat & -2.84488 & 0.0022 & Stationary & Reject H0 \\
\hline DPS & PP - Fisher Chi-square & 62.1951 & 0.0005 & Stationary & Reject H0 \\
\hline & PP - Choi Z-stat & -3.00666 & 0.0013 & Stationary & Reject H0 \\
\hline DPR & PP - Fisher Chi-square & 74.9173 & 0.0000 & Stationary & Reject H0 \\
\hline & PP - Choi Z-stat & -4.11845 & 0.0000 & Stationary & Reject H0 \\
\hline
\end{tabular}

Source: Extract from E-view 9.0

\section{Discussion and Analysis of Results}

Dividend decisions have long been the most controversial issue in corporate finance among scholars (Olowe, 20I I). The pattern of corporate dividend decisions not only varies overtime but also affect by internal and external factors of the firm. The issue of dividend decisions has long been one of the most controversial issues among scholars in the field of corporate finance. From the opinion of Gordon's, the Dividend policy is relevant while from the opinion of Miller and Modigliani dividend policy is irrelevant under specific assumptions that the market is perfect. The question that boarder most scholars is that can there be any perfect market that can make dividend policy irrelevant? For instance, the financial market of the developing countries specifically Nigeria is known for its imperfection because it is characterized with insider dealings where stock brokers are also floor dealers (Onoh, 2002). This justifies the agency theory as noted by Jesen (1979). The a-priori expectation of the result is that the independent variables are expected to have a positive impact on shareholders' return of the quoted commercial banks.

The results of the regression model found that the independent variables can explain 5 percent variation on economic value added from the pooled regression results, 75 percent variation from the fixed effect results and 44 percent from the random effect (table ii, iii and iv) Results from model found that dividend yield have negative effect on economic value added while dividend per share, dividend payout ratio and retention ratio has positive and significant effect on economic value added of the quoted manufacturing firms. The positive impact of retention ratio and dividend per share confirm the a-priori expectation of the result and justifies the objective of constant dividend policies. Retention ratio is a source of internal investment. Increase in retention ratio makes the company to be less levered which means that significant proportion of corporate investment is financed by equity capital. This makes corporate organizations not to face leverage risk. It also makes the organization to grow as noted by Pandey (2005). The positive effect of the variables confirm the findings of Agyei and MarfoYiadom (20II) whose results found positive relationship between dividend policy and performance, Uwuigbe, Jafaru and Ajayi (2012) Whose result shows a significant and positive association between the performance of firms and the dividend payout. Merekefu and Ouma (2012) whose findings revealed positive strong relationship between Net profit after tax and dividends and the findings of Timothy and Peter (20I2) findings indicated that dividend payout was a major factor affecting firm profitability measured by net profit after tax. The negative impact of dividend yield is contrary to the expectation of the results and can be traced to monetary policy shocks that affect the performance of the manufacturing firms over the period. The negative impact is contrary to the findings of Gul (2012) who found that the market value of companies that pay dividends is well above the book value as compared to companies that do not pay dividends and the findings of Salehnezhad (2013) who found a positive relationship between financial performance (stock returns) and dividend policy. However, evidence from the cross-sectional 
comparison found that variables are statistically not significant (table $v$ ) which implies that there statistical differences between fixed and random effect models. The granger causality test found that there is no causality between the variables, this findings is contrary to the expectation of the results (table vi) and can be traced to poor performance of the firms over the periods covered in this study. The variables are stationary from the results of the stationarity test (table vii).

\section{Conclusion}

The objective of this study was to investigate the effect of dividend decision on economic value added quoted manufacturing in Nigerian. The study made use of secondary data from financial statement of the quoted manufacturing firms. The Hausman test validated the use of fixed effect model. From the results the study conclude that dividend yield have negative and significant effect on the economic value added of the manufacturing firms, this implies, variation on dividend yield of the firms will significantly reduce economic valued added. Dividend per share have positive and significant effect on the economic value added of the manufacturing firms, this implies, variation on dividend per share of the firms will significantly increase economic valued added. Dividend payout rate have positive but insignificant effect on the economic value added of the manufacturing firms, this implies, variation on dividend payout rate of the firms will not significantly affect economic valued added. Retention rate have positive and significant effect on the economic value added of the manufacturing firms, this implies, variation on retention rate of the firms will significantly increase economic valued added.

\section{Recommendation}

From the findings, the study made the following recommendations:

- The cross sectional data indicates that the manufacturing dividend decision was a constant dividend decision, therefore we recommend that constant dividend decision should be maintained among the quoted manufacturing firms.

- Retention forms should be properly invested and the investment environment should be well managed to increase shareholders return through the dividend decision channel.

- The management should devise measures of managing shareholders to achieve shareholders wealth maximization through Dividend policy and the operational environment of the quoted manufacturing firms should be integrated with the companies' operating objectives to achieve the objective of the shareholders.

- The negative effect of the independent variables could be traced to poor corporate governance and poor optimal capital structure, therefore we recommend that the operating leverage and the capital structure of the firms should be examined or revisited to enhance profitability performance of the quoted firms and corporate governance should be ensured in the management of the firms to enhance the profitability performance that will affect positively the dividend policy.

\section{References}

Agyei, S. K., \& Marfo, Y. E. (20II).Dividend Policy and Bank Performance in Ghana, International Journal of Economics and finance, 3(4),23-42.

Ajanthan, A. (2013). The Relationship between Dividend Payout and Firm Profitability: A study of listed Hotels and Restaurant companies in Sir Lanka. Research Journal of Finance and Accounting 4(IO), II5-I26.

Akani, H. W., \& Lucky, A. L., (2015). Econometric analysis of capital adequacy ratios and the impact on profitability of commercial banks in Nigeria. IOSR Journal of Economics and Finance, 6 (6), II - 24.

Akani, H. W., \& Lucky, A. L., (2016). Capital structure and shareholders' value of commercial banks in Nigeria: A multi-variate study analysis. IIARD International Journal of Economics and Business Management, 2 (5), I - 24.

Anyamaobi, C., \& Lucky, A. L., (20I7). Corporate characteristics and value creation: A panel data evidence of Nigeria quoted manufacturing firms. World Journal of Finance and Investment Research, 2(I), 3I-49.

Azhagaiah, R., \& Priya, N.S. (2008). The impact of dividend policy on shareholders' wealth. International Research Journal of finance and Economic, 3(8), I80-I87.

Bell, L.W.W., (1998) Economic profit: an old concept gains new significance. Journal of Business Strategy, 19, 5: 13-15.

Bhattacharya, S., (1979).Imperfect information, dividend policy, and the bird in hand fallacy. The Bell Journal of Economics, IO, (I), 259-270.

Chen, S., \& Dodd, J.L., (I977) Economic value added (eva): an empirical examination of a new corporate performance measure. Journal of Managerial Issues, 9, 3: 318-333.

Eniola, O. J. \& Akinselure, O.P. (2016).Impact of divided policy and earnings on selected Quoted companies in Nigeria. International Journal of Innovative Research and Development, 5(6), 308-32I.

Ezirim, B. C., (2005). Finance dynamics: Principle, techniques and application. Markowitz Centre for Research and Development. 
Fathima, T, (2014). Impact of dividend payout on corporate profitability: evident from Colombo stock exchange. Advances in Economics and Business management I(I), 27-33.

Gordon, M. J. \& Shapiro, E. (1956). Capital equipment and analysis: The required Rate of Profit. Journal of Management Science 31, IO2-IIO.

Gordon, M. J. \& Lintner, J. (I959).Dividends, earnings and stock prices. Review of Economics and statistics, 4(I), 99-I05.

Gordon, M., (1960). The savings, investment and valuation of a corporation. Review of Economics and Statistics, 37-5I.

Graham, B., Dodd, D, (1934).Security analysis, Ist edition, McGraw-Hill, New York. International Journal of Economics, Commerce and Management, 3 (4), I-I3.

Gul, S., (2012). The Relationship between Dividend Policy and Shareholders Wealth (Evidence from Pakistan), Economic and Finance Review, 2(2), 55-59.

Ifuero O. O, (2016). Does dividend policy affect firm earning? Empirical evidence from Nigeria. International Journal of Financial Research, 7 (5), 77-86.

Jensen, M. C. (1979). Agency costs of free cash flow, corporate finance, and takeovers. The American Economic Review, 7(6), 323-329.

Lee, B. (1996). Causal relations among stock returns, interest rates, real activity and inflation, Journal of Finance, 47, I59I I603.

Lehn, K., \& Makhija, A.K., (1997). EVA, Accounting Profits, and CEO Turnover: An Empirical Examination, I985-I994. Journal of Applied Corporate Finance, IO( 2), 90-97.

Lintner, J., (1996). The Potential Role of Managed Commodity-Financial Futures Accounts (and/or Funds) in Portfolios of Stocks and Bonds. The Handbook of Managed Futures: Performance, Evaluation \& Analysis. Ed.

Lucky, A. L., (2017). Cost of capital and corporate earning of quoted firms in Nigeria: A Multi-Dimensional Analysis of quoted firms in Nigeria. Australian journal of finance and banking review, I(I), 4I-65.

M Rabet R., \& Bouffat W., (2016). The relationship between dividend policy and firms performances: A study of listed companies in morallo. European Scientific Journal. I2(4), 469-482.

Marshall, T. H. (1920). Reappraising "Social citizenship in the twenty - first century. Journal of Citizenship studies I8, 3-4.

Merekefu, T. M \&Ouma, O. P. (2012). Dividend Policy and its impact on firm value: A Review of Theories and Empirical evidence. International Journal of Scientific and Research, 22(2), 2-4.

Miller, M \& Modigliani, F (I96I) Dividend policy, growth and the valuation of shares. Chicago Journals, 3(4), 4II-433.

Momgbe T.G \& Ibrahim A.A (2014). Dividend policy on financial performance: A case study of selected Resgistred firms in Nigeria. Research Journal of finance and Accounting 6(20), I-2.

Nwamaka, O. C., \& Ezeabasili, U. (2017). Effect of dividend policies on firm value: Evidence from quoted firms in Nigeria. International Journal of Management Excellence, 8(2).

Ojeme, S, Mamidu, A, I. \&Ojo, J. A. (2015). Impact of dividend policy on shareholders wealth: a study on manufacturing industry listed in Nasdaq, America. International Joumal of Accounting \& Business Management, 4(2), 607-619.

Olowe, R. A.(20II). The impact of 2004 banking capital announcement on the Nigeria stock market. African Journal of Management, 2(2), 180-201.

Onoh, J. K. (2002). Dynamics of money banking and faineance in Nigeria: An emerging market. Astra meridian publishers.

Osegbu, I. F., Ifurueze, M., \&Ifurueze, P., (2014).An analysis of the relationship between dividends payment and corporate performance of Nigerian banks. Global Business and Economic Research Journal, 3(2), 75-99.

Osegbue, I. F., et al. (20I4).An analysis of the relationship between dividend payment and corporate performance of Nigerian banks. Global Business and Economics Research Joumal, 3(2), 75-95.

Oyinlola, O.M., \&Ajeigbe, K.B., (2013). The impact of dividend policy on stock prices of quoted firms in Nigeria. International Journal of Economics, Commerce and Management, II (9), I-I7.

Pandey, I. M. (2005). Finance management, $9^{\text {th }}$ edition, VIkas Publishing house PVT Ltd.

Peter E.A., \& Lyndon M.E., (20I6). Dividend payment policy and performances evidence from Nigeria. Social sciences learning education Journal I(I), 6-9.

Riahi-Belkaeoui, A., (1993). The information content of value added, earnings, and cash flow: us evidence. The International Journal of Accounting, 28(I), I40-146.

Rogerson, W.P., (1977). Intertemporal cost allocation and managerial investment incentives: a theory explaining the use of economic value added as a performance measure. Journal of Political Economy, 105, (4), 770-795.

Salehnezhad, S. H. (2013). A study relationship between firm performance and dividend policy by fuzzy regression Iranian scenario. International Journal of Accounting and Financial Reporting, 3(2), 4I-69.

Shapiro, D. (1990). What went wrong? Journal of Corporate Accounting \& Finance, 24(4) 49-53.

Simon-Oke P.O., \&Ologunwa O.P., (2016).Evaluation of the effect of dividend policy on the performance of corporate firms in Nigeria. FUFA Journal of management and Technology maiden Edition III-I20. 
Simon-Oke, O. O., \&Ologuntra, O. P. (2016). Evolution of the effect of Dividend Policy on the performance of Corporate firms in Nigeria. FUTA Journal of Management and Technology Maiden Edition, III -I2O.

Skinner, D. J. \&Soltes, E. (20I I). What do dividends tell us about earnings quality?

Spyrou, S. (200I). Stock Returns and Inflation: Evidence from an emerging market. Article in Applied Economic Letters 8(7), 447-450.

Stulz, R., (2000). Merton Miller and modern finance. Financial Management, 29(4), II9-I3I.

Suranta, E., \& Machfoedz, M.,(2003). Analisisstrukturkepemilikan, nilaiperusahaan, investasi, danukurandewandireksi.SimposiumNasionalAkuntansi, 6, 214-226.

Taimi M. E., (20I4). Dividend Policy and Its Impact on Firm Value: A Review of taxes. American Economic Review, 60, I-40.

Timothy, M. M., \& Peter O., (2012). The Relationship between Dividend Payout and Firm. Theories and Empirical Evidence, I-33.

Tiriongo T. K. ,(2004). Dividend Policy Practices of the Companies Listed at the Nairobi Stock. Exchange, Unpublished MBA Project University of Nairobi.

Travlos, W. Trigeorgis, L. \&Vafeas, W. (200I). Shareholder wealth Effects of Dividend Policy Changes in an Emerging Stock Market: The case of Cyprus. Multinational Finance Journal, 5(2), 87-I I2.

Urouigbe U., (2012). Dividend policy and firm performance: A study of listed firms in Nigeria. Accounting and management information system. II(3), 442-454.

Uwuigbe, U., Jafaru, J., \&Ajayi, A., (2012). Dividend policy and firm performance: a study of listed firms in Nigeria. Accounting and Management Information Systems, II(3), 442-454.

Vogt, R. D. (1994). The source of investment cash flow sensitivity in manufacturing firms: Is it Asymmetric information or Agency Costs?

Walter, J. E., (I963). Dividend policy: its influence on the value of the enterprise. of Economics, Commerce and Management, $I I(9), I-I 7$.

Wolmarans, H., (2003). Does Lintner's dividend model explain South African dividend payments? Meditari Accountancy Research I(I), 243-253.

Yusuf B. R., (2015). Dividend payment and performance of deposit money banks in Nigeria. International Journal of Achiness in management and economics. 4(6), 98-105.

Zhou, P. \& Ruland, W. (2006).Dividend payout and future earnings growth. Financial Analysts Journal, 62(3), 58 - 69.

\section{Copyrights}

Copyright for this article is retained by the author(s), with first publication rights granted to the journal. This is an open-access article distributed under the terms and conditions of the Creative Commons Attribution license (http://creativecommons.org/licenses/by/4.0/). 